\title{
A Follow-up Study in Psychoanalytic Psychotherapy of Couples
}

\author{
Maria G. Rios-Lima, Is abel C. Gomes* \\ Department of Clinical Psychology, Universidade de Sao Paulo (USP), Sao Paulo, Brazil
}

\begin{abstract}
During 11 years we have been working on a research involving intervention with families seeking treatment in a couns eling center-school and whose complaints are focused on their children. Using psychoanalytic psychotherapy with the couples, we have tried to achieve symptom remission in the children. The purpose of this study is to reflect on the maintenance, over time, of the psychological changes obtained in this kind of clinical practice, which encompasses both couples and families. Based on clinical-qualitative methodology and case study, two cases have been examined, with emphasis on the follow-up sessions for two couples who were undergoing psychoanalytic couple's therapy for thirty-six and thirty months, respectively, with two additional follow-up sessions after the therapy was finished. The collection of clinical material to be analyzed according to the psychoanalytic references was made using excerpts from the session written notes taken by the therapist herself immed iately after the sessions were over. As a result, this kind of intervention proved effective in clarifying latent marital conflicts and in fostering a healthy environment, one that could contribute to the emotional development of the child.
\end{abstract}

Keywords Interview, Follow-up, Psychoanalytic Therapy, Couples Therapy

\section{Introduction}

We have been working for 11 years on a research project involving a proposal of intervention for couples and/or families who seek treatment in a counseling center-school that is part of an academic institution and whose complaints are focused on the children[1-3], as described on the item 1.1. More than 70 cases have been treated and they confirmed the hypothesis that psychoanalytic psychotherapy with parents or the whole family has a strong effect for the child's symptomatic remission. This project is based on three elements: co mmunity service, c lin ical training of psychology students - the service is provided by student trainees under supervision -, and the production of systemic theoretical knowledge. The last element created the need to assess the effectiveness of this intervention over time, which created a deriving interest in investigating whether the results obtained - the child's "healing" and his/her repositioning within the family and/or conjugal structure - were maintained after the therapeutic process was finished.

In order to do so, we conducted a follow-up study with two couples, A and B, who underwent psychoanalytic couple's therapy for thirty-six months and thirty months, respectively.

Each couple had two follow-up sessions - with couple A,

* Corresponding author:

isagomes@usp.br (Isabel C. Gomes)

Published online at http://journal.sapub.org/ijap

Copyright (C) 2012 Scientific \& Academic Publishing. All Rights Reserved seven months and 16 months after the end of therapy; with couple B, seven and 19 months after the end of therapy. The collection of clinical material to be analyzed according to the psychoanalytic references was made using excerpts from the session written notes taken by the therapist herself immed iately after the sessions were over. As a result, this kind of intervention proved effective in clarifying latent marital conflicts and in fostering a healthy environment, one that could contribute to the emotional development of the child.

The purpose of this article is, thus, to reflect on the maintenance, over time, of the psychological changes that occur in this specific type of couple's therapy, which encompasses the marriage and family spheres.

\subsection{A S pecific Therapy for Couples}

Considering how often a child's symptom can be created by family dynamics, which includes aspects of the conjugal relationship of the parents, we believe that treating the parents can be effective and sufficient for making the child's symptoms disappear.

The first step was to evaluate the child, who was considered "sick" by the family. If the diagnosis confirmed the possibility of the symptom resulting from the conjugal dynamics, the interviews about the psycho pedagogical diagnosis with the parents were made longer in order to raise awareness about the "change in focus" from complaints about the child to them, and then proposing psychotherapeu tic treatment with psychoanalytical orientation, for the 
parents. After the end of the psychotherapy with the parents, we would re-evaluate the child to see if he/she had stayed in remission[2].

In the course of the clinical experience and research with the families served, and after we gained a better understanding of the conjugal dynamics and possibilities of changes in these relationships, we chose to skip the step of direct evaluation of the child, in the cases in which the complaints were not specific and when the couple already mentioned some conjugal and/or family conflict in the first interview. We started to offer couples therapy directly. As our theoretical base we used the tenets of couples and family therapy themselves, which point to the close link between conjugality and parenting.

In the early studies of family therapy, Ackerman [4] stated that often the true nature of the conjugal conflict was denied, displaced or projected on other family ties, such as those between parents and children, thus confirming our current findings. Eiguer[5] coined the expression "couples therapy" to refer to another approach to couples that highlights parenting when, due to the limitations with the child, it is not possible to have family therapy.

In accordance with the above reasoning, a clinical therapy for couples was established, with the complaints focusing on the child's symptoms as an intermediate way to get to the conjugal conflicts which, for their part, interfered in the establishment of a healthy family environment. The two clinical cases discussed in this article involved therapy provided in the second stage of the project, and no child was evaluated.

This specific therapeutic process involves the review of family and conjugal ties, taking into account their transgenerational aspects and psychopathology, according to Kaes[6] and Correa[7-8]. It also involves the basic references of families and couples psychoanalytic therapy, according to Eiguer[9] and Berenstein[10]. We can see here the need to supplement the therapist's view with the psychosocial studies that mostly discuss changes in today's families and marriages[11-12].

In this clinical practice the goal is to recover a space of conjugality for the parents, sometimes lost or never even created, in order to strengthen or change it, in terms of creating a healthier environment for the whole family. In cases of more serious pathologies involving couples, the goal is to establish a distinction between the conjugal and parental spheres, in an attempt to ensure a min imum balance into the family dynamics and distinguish different places in the relationships between parents and children[3]. In cases of crisis involving the whole family, such as in deaths and breakups, we also believe that couples or family therapy can be more effective than treating one member of the group individually, thus corroborating other studies about family and couple therapy[13-15].

Thus, the purpose of this intervention is based on two key aspects: to understand and to change the focus from complaints about the child to the couple, an approach that seeks to eliminate the "sick" role such a child occupies in the family, and thus to bring to surface the couple's conflicts, an attempt at "recovering the conjugal aspect"[2].

In this kind of indirect-demand therapy, the work with couples presents some difficulties, mainly those related to the resistance, by the couple, regarding the change of the complaints - moving from the child to the couple[16]. But in the cases when the work with the parents is possible, the results have been encouraging, bringing positive changes in the child and in the family context. A lthough these results can be confirmed at the end of the therapy, studies involving the monitoring of such cases after the end of the therapy or as follow-up practices hadn't been made in the intervention and research project.

\subsection{Follow-up studies in Psychoanalysis and in Couples and Family Ther apy}

Follow-up studies have proved to be a useful strategy in reviewing the efficacy of different types of therapy in psychology, including psychotherapies based on psychoanalysis[17]. The search in international databases such as PsychINFO and MedLine, using "psychoanalysis" and "follow up" as key words brings 131 articles and chapters of books published since the year 2000. Forty-eight of these references are related to studies or reflections about the efficacy of different types of psychotherapy, with the evaluation of the maintenance of the results over time, after the end of the intervention. These studies were conducted in a few European countries, especially in Germany and England, and also in the United States. Only one of them involves a South American country, Chile, and it is a comparison between psychoanalytic techniques, dynamic, cognitive-behavioral therapy and supportive psychotherapy in the treatment of patients[18]. None of these studies deals with couples or family therapy using a psychoanalytic approach.

It is interesting to think about the relationship between psychoanalysis and follow-up strategies originally used in quantitative studies, often as a positivist basis for knowledge buildup, a practice which clashes with the assumptions of psychoanalysis as a science and therapeutic technique. According to Orfanos[19], psychoanalysis has developed greatly in the last 25 years, either theoretically or in the clinical and research areas. Regard ing the latter, the author highlights follow-up studies which examine the lasting effects of the treatment.

Wallerstein[20] conducted an extensive study on follow-up and psychoanalysis, in which he discussed the use of this strategy and its effects on the relationship between analyst and analysand, emphasizing the interference in the preparation of the end of treatment. However, he concludes in favor of the use of this strategy and gives examples of contacts Freud kept with his analysands after they were analyzed.

In his research, which included follow-up interviews conducted two and three years after the end of the analytical process, Wallerstein[20] concluded that the impact of a planned follow-up study at the end of therapy and on the 
effect of psychoanalytical theories, although not always consequence free, does not seem harmful and can be extremely helpful to the therapeutic endeavors of both analysts and analysands.

There are many factors that need to be taken into account in psychoanalys is in order to understand the progress of previous analysands and to assess whether analytical outcomes can be maintained or not. A mong these factors are the external conditions of life, as well as the support systems established and the family environment[20]. It is also relevant to examine in which conditions the end of treatment happened, i.e., if it was decided together by analyst and analys and or if it was "forced" by the analyst. There are also other important aspects that influence post-therapy development, and which have not been totally or suffic iently examined during the analytical process.

Szecsödy[21] contributed to this topic by seeking to understand the process of termination and any contacts kept after that, emphasizing the resistance by some analysts themselves in monitoring the effects of the analys is through the use of follow-up interviews. He reflects that, in order to psychoanalys is to survive, it is critical that we face the challenge of the lack of well-documented research, which confirms the value and efficacy of psychoanalytical treatment. In h is view, follow-up studies provide not only the external legitimization of psychoanalys is, but also represent a fruitful method for studying the changes in the psychoanalytical method.

For Leuzinger-Bohleber, Stuhr, Ruger and Beutel[22], the increasing scientific and public pressure for obtaining evidence on psychoanalysis' efficacy as a psychotherapeutic method to be funded by health insurance plans, has caused psychoanalysis to elaborate its own arguments, in accordance with its specificity, and to accept the challenge to pursue its own follow-up studies on therapeutic effectiveness over time, within a psychoanalytical rationale.

Studies using follow-up procedures have become co mmon over the last decade. DeMaat, Philipszoon, Shcoevers, Dekker and DeJonghe[23] conducted research on the costs and benefits of long-term psychoanalytical therapies. They conducted a systematic review of the studies published between 1970 and 2005, reviewing those considered as the strictest. They concluded that long-term psychoanalytical therapy reduces significantly the use of health services, even after the end of therapy. In the focused studies, the average follow-up time was 33 months, during which time therapy outcomes were kept.

There is some controversy around the question of establishing a period after the end of therapy or intervention for the follow-up interview, and it varies in the different articles reviewed. Research that involves psychoanalytical references show clearly that the shortest intervals before the first follow-up interview are three months[24] and six months[25-26]. There are many studies in which the minimu m interval is one year[27-31]. A mong the studies that show a longer interval between the end of the intervention and the follow-up review, this interval can be from four to eight years [32-36], and up to 15-20 years[37-38]

As for couple's therapy, the only article found in the international databases consulted, including the descriptors "follow up" and "couples therapy" has a behavioral orientation[39].

Although two studies were found in these databases which discuss "follow up" and "family therapy", as of 2000, only one of them referred to evaluations of types of therapy that involve a stage after the end of therapy. It is the study by Wallin and Kronvall[40] on nervous anorexia in teenagers. This study examines changes in the family operation after the end of family therapy. The interval for follow up chosen was two years.

In Brazil, a search for follow-up studies in the SciELO database brought about 22 articles, but all of them in the medical area. In Dedalus, the Universidade de São Paulo's database, there are 19 articles. Among those reviewing specific types of psychotherapy, we highlight the following: Gebara, Rosa, Simon and Yamamoto[41] examine the therapeutic effectiveness of the interpretation presented as a theory in the method denominated "Short-term Psychotherapy under a Psychoanalytical Approach", using follow-up data. Outside the field of psychoanalys is, there are studies such as those by Oliveira[42], and by de Silva, Facco and Silvares [43], in which the intervals for the follow-up varied from six months to two years in the first, and seven months in the second.

The differences in the findings of so many studies may be due to many methodological factors, as Wallerstein notes[20]. A mong them are: the variable number of subjects; the clinical population studied, which includes the severity of the sympto ms presented and the different life contexts; the level of training of the analysts; the instruments for evaluation, and the way in which these instruments are evaluated.

\section{Method}

The present project used the case study as part of a qualitative research proposal in the clinical area. The choice for clinical studies, which differed among themselves in many aspects, was made according to the idea that in qualitative research the participants should be selected purpos efully, with a deliberate choice of respondents, based on experience and on the investigator's actual possibilities [44].

\subsection{Participants}

Two clinical cas es were chosen, both attended to by one of the authors of this paper, who was then an undergraduate student and recipient of a scientific in itiation scholarship, and was doing a project internship. From the beginning of the therapeutic process, the couples were aware they would be responding to follow-up interviews. 


\subsection{Ethical Consider ations}

Since the services were provided in the counseling center-school, they followed the ethical standards established by the institution, i.e., during the screening, each client signs an informed consent form allowing the use of the material for research. In the current study, the names of all the participants have been changed.

\subsection{Proce dures}

Data collection

The sessions with the couples were conducted at the counseling center-school, with the presence of both spouses. Because of the moment in which the therapy started and the uniqueness of the conjugal and family dynamics, in the case of couple B, a newborn was introduced in the setting. The sessions were not recorded and were always held in the same room and scheduled in advance. The therapist who conducted the therapy was the same who conducted the follow-up sessions for both couples.

The collection of clinical material to be analyzed was made using excerpts fro $m$ the session written notes taken by the therapist herself immediately after the sessions were over, and which include records of impressions and feelings related to counter-transference that emerged during the session. All sessions were individually supervised and the notes related to the supervision were used to drill down the analys is.

We agree with Pavanelli[45] when he says that the writing of a case by the therapist can be considered a privileged form of mediation, and more than that, a passage from theory to practice which thus becomes an important working tool for the psychoanalyst/clinical psychologist. The author considers that it is essential to have the ability to distance herself - and also to get closer - fro $\mathrm{m} /$ to the clinical experience in order to reflect on it. The quotes included reflect the actual words of the patients as the therapist remembers them.

Couple A, Leda and Ari, underwent couples psychoanalytical therapy for three years, from 2003 to 2006, once a week. The first follow-up session was held seven months after the end of the intervention; the second, 19 months after the therapy ended. Couple B, Anita and Rui, underwent therapy for thirty months, from 2003 to 2005 , once a week during 24 months and biweekly from then on. The change in frequency was made mutually by the couple and was based on the development of the psychotherapeutic process. The follow-up sessions took place seven months and 16 months after the therapy was finished. In both cases, there was no concomitant therapy.

The criteria for establishing the intervals for the follow-up interviews, based on the literature reviewed, were approximately six months after the end of therapy, in the first case, and 18 months in the second. There were minor changes as a result of changes in the school calendar, such as vacations in July, the Holiday seas on, strikes, etc.

The couples were contacted by the therapist by phone, when it was time for the interviews, which were conducted in the same setting that had been previously used.

Data analys is

Data was analyzed by emp loying interpretative activities grounded on psychoanalysis literature, which allowed the reaching of certain conclusions based on the notes taken during the sessions. We would like to stress that the following were considered as indications that psychological changes obtained in therapy were sustained: reporting by the spouses that they had made changes and/or improvements and that remission of their child's symptoms had occurred; their own reflections on their psychotherapeutic process, focusing on the distinction established between the conjugal space and the parental space. The therapist's observations were also included in the analysis - the way the couple positioned themselves in the room, their verbal and non-verbal interactions, their attitudes during the session and the counter-transference feelings the therapist experienced.

\section{Results and Discussion}

\subsection{Couple A}

Family characterization: The family was composed of the couple - Leda, 49, and Ari, 60 - and two children - a girl, 7, and a young man, 26. The oldest son was finishing college in the state of Paraná, Brazil, and visited his parents' house sporadically. Leda worked hard as a teacher, taking many courses and sometimes traveling to work as a consultant in other cities. Ari worked in a company and was about to retire.

The complaint the couple brought to therapy was related to the daughter, Lucia, whose behavior included robbery and lies. The girl performed well at school and was sociable. The first sessions were marked by Leda's complaints about her husband and his apparent lack of interest and apathy regarding the daughter's symptoms and everything the wife said. From the second session on, they didn't talk about the daughter's problems, but about how these problems affected them, which highlighted the latent conjugal conflicts. The family environment was characterized by the intense irritability of both spouses, and their frequent arguments and fights. Leda and the daughter paired up, and Ari was left out - and allowed it to happen. The couple did the same in the clinical space, in terms of transference. Leda established a connection with the therapist and Ari placed himself as an outsider, showing no desire to participate.

Regarding the couple's history, they were dating when Leda got pregnant of their first son, so they decided to get married. The conjugal aspect of their relationship came to be because of the parenting aspect. This happened again in the second pregnancy, which was not planned, and which occurred when Leda was 40 years old and medically considered as infertile. This led us to think that the fact that the oldest son was already a 18-year old grown up was such 
an unbearable feeling for the couple, that another child had to come fill the place about to become empty, which confirms how fragile the conjugal tie was for this couple with a weakened conjugal identity[46], one that lacked common projects and desires.

Another important aspect of the conjugal and family dynamics was related to the way that the couple dealt with their careers and means to support the family. Both worked, but the wife's involvement with work seemed to be bigger than the husband's, as well as her earnings. She worked exhaustively, and often delegated the domestic tasks and daughter's care to the husband. After many professional failures, the husband was unemployed and waited for retirement, so he stayed home most of the time. This division of tasks, typical of contemporary life, resulted in many arguments and brought to surface the old dilemma of the interference of traditional models in families organized around more democratic relationships.

After clarifications regarding the initial complaints, it was possible to work, over the psychotherapeutic process, on many aspects of the conjugal and family dynamics, such as the conjugality established around parenting and the need to introduce a third person between them - either the second child or the wife's excessive work; the wife's ambivalence regarding her roles as a mother, wife and professional; the division of domestic tasks and the interference of the traditional family model. Also, instead of being seen as the "sick" person in the family, the girl started to be seen as the one who exposed the conjugal conflicts of her parents, who then recognized they needed help.

Over time, with therapy, the remission of the child's symptoms occurred, and the couple gradually started to show new ways of connecting to each other, creating projects in common and establishing a space for reflection and for attempts at renewing their relationship, and the resistances that had aroused were overcome. Although improvements were made through therapy, both had difficulty in extending them to their daily lives, since in the analytic setting they could count on a third person involved to help them, the therapist.

As a clinical strategy, it was decided that after 30 months of therapy, an additional six months before the end of the therapy would be used to challenge the couples' dependence on only touching the most conflicting aspects of the conjugal ties in the presence of the therapist. This technique of establishing a deadline is not new in psychoanalytical practice, and characterizes short-term therapies. However, it was Freud[47-48] who introduced this topic and pointed out that the establishment of a deadline for the therapy to fin ish should only be used in special circumstances, main ly when there is stagnation in the therapeutic process. This paralys is can be caused by an exaggerated dependence on the analyst, which can become more intense when we thin k of the group setting.

During the last six months of therapy, a development on the conjugal relationship of the couple was noticed, although at the end of the process Leda seemed to be resentful with the end of therapy. According to the couple, they appreciated "the focusing on them, instead of the daughter", as if this was already a major achievement, but seemed to be concerned about facing the future without therapy, especially the wife.

In the first follow-up session, seven months after the end of the therapy, the couple had not yet accomplished most of their common projects, and had in a way reverted back to the kind of relationship they had before they started therapy. Leda was still using the excess of work as a defense to keep away from her husband. However, they had stopped blaming the daughter for their problems, and the girl showed a satisfactory development, with no complaints. In Leda's words:

What you do here, calling the parents[to therapy] instead of the child, it was very good in our case. Lucia is really well! It is up to us now.

I was afraid I wouldn't be able to talk to him, but we are getting there.

It is not that I don't miss it (referring to therapy), but we are getting there...

In spite of this comment from Leda, the session was marked by the couple's irritability toward each other, by Leda's complaints, by the distance Ari kept. It seemed that the only permanent change had been the total remission of the daughter's symptoms; it seemed that the couple wouldn't be able to recreate their conjugal dynamics.

In the second follow-up session, however, this hypothes is was abandoned. In the beginning of the session, the couple showed some distance and irritability, but ended up showing that some of the progress achieved at the end of the therapy had finally been consolidated. They talked about the projects they had in common, and about having a more satisfactory experience together, valuing the existence of a conjugal space that allowed for complicity and how they spent more time together and were involved in activities together. Leda had been able to make non-excluding choices between work and home. Ari had the chance to be closer to his daughter, sharing the task of her education without distancing himself. It was clear that both had recognized the importance of being able to communicate in an effective way, and they credited that to therapy: ("I came to therapy with some reservation. But Iopened myselflittle by little, I talked more, and that was good..." Ari) and ("It is true. At that time[referring to the beginning of therapy] Iwas in a whirlwind. Things were very difficult for me. Now it is possible to talk... "Leda).

They sat together, and even hugged during the session, which had never happened before. Ari expressed his opinions more intensely than he usually did. As it had been reported in the previous follow-up session, the daughter was doing well, all her previous symptoms had disappeared, and there were no complaints about her.

The therapist's interpretation, during the session, was that in the first meeting after the therapy ended, it was as if they were still resentful about the way the therapy had ended. However, after they realized they had to "walk with their own feet", they allowed themselves to enjoy all the benefits that therapy had provided. Learning and valuing the conjugal 
space, respecting their individuality, having each the right role to play in the family, and most of all, not using the daughter as an embodiment of their marital conflicts.

\subsection{Couple B}

Family characterization: The family was composed of the couple, Anita, 27 and Rui, 35, and three children. The oldest was six years old, the second had died at the age of three, and the third was a baby.

This case was different from the other in that the couple had been referred to therapy after the psycho diagnos is of the oldest son, João, who was then six years old. The diagnosis had been given by another therapist because of a fa mily cris is, the death one year before of Carlos, who was then the youngest child. In the beginning of the sessions, Anita was pregnant with a girl, whom the parents had decided to name Karla.

After the therapy started, it was interrupted for 50 days upon Karla's birth. When sessions resumed, the baby started to come to the weekly sessions with her parents, both because there was nobody else to stay with her, but also because her presence would prevent her from replacing a position occupied by the dead boy, as her name seemed to clearly indicate. After two years of therapy, the sessions started to be held every two weeks, and were finished after 36 months.

Reflections on this clinical case, on the way it has been handled, the analytical setting where an infant was always present, and the theoretical references used have already appeared in a previously published article[49]. Here, we will talk briefly about the couple's psychotherapeutic process, and the follow-up sessions.

The couple functioned in a rigid complementary way[50], with Anita fulfilling the role of the weak, incompetent, almost inadequate party, while Rui played the strong role, i.e. the person who solved everybody else's problems. The family crisis made it hard on the family to sustain this dynamic. Rui had difficulties in expressing himself verbally and dig into the suffering caused by the loss of a son. However, he was clear about accepting to go into therapy to help his wife, who needed to get better and learn "to take better care of herself".

Therapy offered them a space to face this situation, and the therapy focus was on type of ties connecting the couple. They established a more flexible connection, which allowed for the creation of a health ier environ ment for the emotional development of the son and in fant daughter. Rui allowed himself to recognize some of $h$ is weaknesses and anxieties, and Anita started to take on more responsibilities which were previously her husband's, such as helping the son with his homework and creating a liaison with the boy's school[49].

The therapy with this couple had a preventive aspect, and removed Karla from the place where the parents tried to put her, as the child who had come to replace the dead brother, Carlos. By allowing them to deal with the traumatic experience of the loss that had affected the family, the therapy made it possible for the couple to face the reality of the tragedy, which was previously approached as something unspeakable. After two years of therapy, Rui was able to say that he thought Karla might be the reincarnation of Carlos, but the daughter's reaction - to walk toward the father and throw up - seemed to have released her fro $m$ this role.

In the first follow-up session, seven months after the therapy finished, the couple had maintained the flexibility they had achieved in their relationship. The wife had taken on some responsibilities, and felt capable of monitoring her children's development, while the husband allowed himself to acknowledge his weaknesses and sufferings. The two children showed satisfactory development, and there were no compla ints. In speaking of the therapeutic process, Rui chose to report the improvements he had seen in his wife, without focusing too much on himself:

It had ups and downs (the therapy), but I thin k the very end was particularly good. She changed so much! You know, I came here because of her. It is perfect now! I don't need to worry any more about things, she takes care of them. (Rui)

Instead of lowe ring her head or keeping quiet after hearing Rui's co mments, the way she did when therapy started, Anita said that she also thought the husband was better, and that she was not the only one who had changed. Karla, who was also present in that session was very active, made drawings and gave them to the therapist before leaving.

Karla was also present in the second follow-up session, 19 months after the therapy finished. She was happy and talkative, and had an active participation in the session; she played and made a few comments. According to the parents, she was in perfect health and developing well, although she didn't like to go to school, which she had started three months before.

There were new complaints about the oldest son. The boy had had episodes of convulsion and had been diagnosed as epileptic. The couple worried that the medication was making him too "sedated", which could be the reason for his poor performance in school.

As for the conjugal dynamics, both stated in this second session that the relationship was very good, and that they had been able to maintain what they had gained in therapy: ("It was very good for us. We grew. Today, people don't take advantage of her any more. Do you remember how she was?"); ("I was always the one who was more reserved, I always said that, it was difficult.) (Rui) and ("It is true, before, if he got home in pain, he didn't want to talk about it, and he became nervous... And people say I've changed a lot! Now I am the one who goes out to pay the bills!') (Anita).

We could say that at the end of the therapy and in the follow-up sessions, this couple still maintained a connection that was complementary in nature[50], in which the husband takes the role of the caregiver and the wife becomes the fragile one. The structure of the connection hadn't been altered, but we considered that the complementary aspect had become more flexible and that there was more openness for Rui to get in touch with his own psychological pains, and for Anita to increase her participation regarding the domestic responsibilities and, especially, her attitude toward her 
husband, the therapist and the children.

The great "accomplishment" of this therapy, in terms of conjugal and parenting aspects, was to provide more flexibility for the roles that husband and wife had chosen, and the fact that the daughter was showing a healthy and creative development. In W innicott's terms, this creativity would probably be inhibited if she had to attend to her parents' unconscious demands that she be the reincarnation of the brother who had died.

Approaching both cases with respect to the uniqueness of the path taken in each of them in psychotherapy, we noticed that many changes achieved in therapy were maintained over time, which confirmed the studies about follow up in psychoanalysis by Orfanos[19] and Wallerstein[20],[17]. The couple A maintained a complaint-free relationship regarding their daughter seven months after therapy finished, and 16 months after that. The space for conjugality that the couple had created was also reinforced as the sessions were coming to an end. We should note, in this case, the importance of analyzing a follow-up session by taking into account the therapy context and the way in which it fin ished, as well as the complex relations of transference and counter-transference, as Wallerstein[20] points out.

With couple B, the indications of progress could be seen in the way they were able to maintain an imp roved flexibility in their relationship, although keeping a certain complementary aspect, and especially in the daughter's creative and healthy development. This progress was achieved through therapy and maintained over time.

In both cases, the children's symptoms suggested latent conflicts in the family and conjugal dynamics. The space created by therapy with the couples allowed these conflicts to come to the surface, giving the children the freedom to have a healthy development.

Regarding the therapist's role, who acts as a facilitator for the creation of the conjugal space, as separated from the parenting realm, the follow-up sessions offered the therapist a way of assessing his or her professional skills, and the patients an image of a future state of being that was able to be implemented. However, the definition of a period for the psychological changes to occur or solidify vary on a case-by-case basis, which leads to a controversial issue of the use of this technique in psychoanalysis. That is why there are discrepancies between the periods used in the above mentioned research, and also in the small number of studies that use this technique in psychoanalysis.

\section{Concluding Remarks}

This follow-up study confirmed the hypothesis of possibility of maintenance, over time, of the remission of the symptoms of the child and the psychological changes obtained by the couple, according to the results above. A psychoanalytic approach to couples whose complaints focus on their child's or child ren's symptoms as a way to cover up latent marital and family conflicts suggests that the therapeutic work take the couple as its priority, mainly helping them to make a distinction between the marital and parental spaces. Intervention, in both cases presented herein proved to be effective in fostering a healthy environment for the child's emotional develop ment, offering the possibility to maintain the accomplishments over time.

Follow-up studies, which allow the ongoing assessment of the effectiveness of the strategies of psychotherapeutic interventions, are still not widely used in psychoanalytical psychotherapies, especially in the treatment of couples and families. However, it is generally agreed in the literature on this subject that the long-term processes need to show results, considering health systems requirements and those of other types of institutions that offer these services. For counseling center-schools which dealnot only with patient/therapist, but also with the training of future professionals, this becomes even more important.

This study has the inherent limitations of the case study methodology which, by giving priority to in-depth analysis and the singularities of each case, doesn't allow generalization[51]. Besides, the reliability is conditioned to the use of theoretical references that guide the psychoanalytical psychotherapy of couples and families. Further studies may include a larger a mount of cases or, also, an independent evaluation of the process, conducted by independent experts [52].

Research on new types of psychotherapeutic interventions with couples and/or families, in which the changes or outcomes can be maintained over time and can take on preventive characteristics, is important to respond to current human anxieties and sufferings, and does contribute to the development of this specific therapy.

\section{REFERENCES}

[1] Isabel C. Gomes. "O sintoma da criança e a dinâmica do casal”. São Paulo: Escuta. 1998

[2] Isabel C. Gomes. "Uma clínica específica com casais: contribuições teóricas e técnicas". 2006. 126 f. Tese (Livre-Docência Psicologia) - Instituto de Psicologia, Universidade de São Paulo, São Paulo. 2006

[3] Isabel C. Gomes. "Uma Clinica específica com casais: considerações teóricas e clinicas". São Paulo: Escuta / Fapesp. 2007.

[4] Nathan W. Ackerman. "Psicoterapia de la família neurótica". Buenos Aires: Paidós. 1969

[5] Alberto Eiguer. "Clinique psy chanaly tique du couple". Paris: Dunod. 1998

[6] Rene Kaës. "Transmissão da Vida Psíquica entre Gerações”. São Paulo: Casa do Psicólogo. 2001

[7] Olga B. R. Correa. "Os Avatares da Transmissão Psíquica Geracional”. São Paulo: Escuta.2000

[8] Olga B. R. Correa. "Grupo Familiar e Psicanálise: 
ressonâncias clínicas”. São Paulo: Vetor. 2007

[9] Alberto Eiguer. "O parentesco fantasmático : transferência e contratransferência em terapia familial psicanalítica". São Paulo: Casa do Psicólogo. 1995

[10] Isidoro Berenstein. "Del Ser Al Hacer. Curso sobre vincularidad". Buenos Aires: Paidós. 2007

[11] Elisabeth Roudinesco. “A Família em Desordem”. Rio de Janeiro: Jorge Zahar. 2003

[12] Teresinha Féres-Carneiro. "Casal e Família: Permanências e Rupturas”. São Paulo: Casa do Psicólogo. 2009

[13] Magdalena Ramos. “Terapia de casal e família”. São Paulo: Brasiliense. 1992

[14] Magdalena Ramos. "Casal e família como paciente". 2 ed. São Paulo: Escuta. 1999

[15] Rachel Soifer. "Psicodinamismos da família com crianças". Petróp olis: Vozes. 1983

[16] Isabel C. Gomes. Alcances e limites da psicoterapia psicanalítica com casais e famílias. In Feres-Carneiro, T. (Org.). "Família e Casal: arranjos e demandas contemporâneas". (pp. 215-224). Rio de Janeiro e São Paulo: PUC-Rio/ Loyolla. 2003

[17] Robert S. Wallerstein. "Outcome Research". In Gabbard, G.O., Person, E.S. \& Cooper, A.M. (Eds.) "The American psychiatric publishing textbook of psychoanalysis". (pp. 301-315). Washington, DC: American Psychiatric Publishing. 2005

[18] J. C. Perry, M. Duque. "Un estudio controlado alazar en psicoanalisis y otras psicoterapias": Consideraciones y diseno. Revista Chilena de Psicoanalisis, vol 21, no1, pp35-44. 2004.

[19] Spyros D. Orfanos. "On such a full sea: advances in Psy choanalytic Psychology". Journal of the New York State Psychological Association,vol 3, no4, pp 2-8. 2006.

[20] Robert S. Wallerstein. "Psychoanalysis: Clinical and Theoretical". Connecticut: International Universities Press. 1999

[21] Imre Szecsödy. "How can we end psychoanalysis - and still have a follow up for it?" The Scandinavian Psychoanalytic Review, vol 22, n1, pp 48-66, 1999.

[22] Marianne Leuzinger-Bohleber, Ulrich Stuhr, Bernhard Ruger, Manfred Beutel. "How to study the 'quality of psychoanalytic treatments' and their long-term effects on patients' well-being: a representative, multi-perspective follow up study". International journal of psy choanaly sis, vol 84, no2, pp 263-290, 2003.

[23] Saskia De Maat, Franz Philipszoon, Robert Schoevers, Jack Dekker, Frans DeJongue. "Costs and benefits of long-term psychoanalytic therapy: Changes in health care use and work impairment". Harvard Review of Psy chiatry, vol 15, no 6,pp. 289-300, 2007.

[24] Anthony W. Bateman, Peter Fonagy. "Treatment of borderline personality disorder with psychoanalytically oriented partial hospitalization: An 18-month follow up". American Journal of Psychiatry, vol 158, no 1, pp 36-42. 2001.

[25] Rossana Ciano, Pier-Luigi Rocco, Alberto Angarano, Elena
Biasin, Matteo Balestrieri. "Group-analytic and psychoeducational therapies for binge-eating disorder: An exploratory study on efficacy and persistence of effects". Psychotherapy Research. Vol 12, no 2, pp. 231-239. 2002.

[26] K. Leithner, A. Maar, F. Maritsch. "Experiences with a psychological help service for women following a prenatal diagnosis: results of a follow up study". Journal of psychosomatic obstetrics and gynaecology, vol 23, no3, pp. 183-192. 2002.

[27] F. Falkenstrom, J. Grant, J. Broberg, R. Sandell. "Self-analysis and post-termination improvement after psychoanaly sis and long-term psychotherapy". Journal of the American Psychoanalytical Association. Vol 55, no2, pp 629-674. 2007

[28] Tilman Grande, Reiner Dilg, Thorstein Jakobsen, Wolfram Keller, Barbel Krawietz, Monika Langer, Claudia Oberbracht, Sabine Stehle, Margret Stennes, Gerd Rudolf. "Differential effects of two forms of psy choanalytic therapy: Results of the Heidelberg-Berlin study". Psychotherapy Research. Vol 16, no 4, pp. 470-485. 2006.

[29] F. Leichsenring, J. Biskup, R. Kreischer, H. Staats. "The Gottingen study of psychoanalytic therapy: first results". International journal of psychoanalysis, vol 86, no2, pp. 433-55. 2005.

[30] Suzanna Lundblad. "Depressed women in psychotherapy: the nature and persistence of change". International Journal of Psychotherapy, vol 8, no1, pp. 53-63. 2003.

[31] John H. Porcerelli, Barry V. Dauphin, Stuart Ablon., Suzan Leitman, Michael Bambery. "Psychoanalysis With Avoidant Personality Disorder: A Systematic Case Study". Psy chotherapy: Theory, Research, Practice, Train ing, vol 44, no1, pp.1-13. 2007.

[32] Manfred Beutel, Marcus Rasting. "Long-term treatments from the perspectives of the former patients". In Target, M. \& Leuzinger-Bohleber, M. (Eds.) Outcomes of psychoanalytic treatment: Perspectives for therapists and researchers. (pp. 130-142). Philadelphia, PA, US: Whurr Publishers. 2002.

[33] Manfred Beutel, Marcus Rasting, Ulrich Stuhr., Bernrard Ruger, Marianne Leuzin ger-Bohleber. “Assessing the Impact of Psychoanaly ses and Long-Term Psychoanalytic Therapies on Health Care Utilization and Costs". Psychotherapy Research., vol 14, no2, pp 146-160. 2004.

[34] George Garyfallos, Aravela Adamopoulus, Anastasia Karastergious, Maki Voikli, Dimitri Zlatanos, Sofia Tsifida. "Evaluation of cognitive-analy tic therapy (CAT) outcome: A 4-8 year follow up". European Journal of Psychiatry, vol 16, no 4, pp 197-209, 2002.

[35] Wolfram Keller, Gisela Westhoff, Reiner Dilg, Robert Rohner, Hans Henning Studt. "Efficacy and utilization of health insurance in patients undergoing long-term psychoanaly sis: Results of an empiric follow up study on the efficacy of (Jungian) psychoanalysis and psychotherapy". Analy tische Psychologie, vol 32, no 125, pp 202-229, 2001.

[36] Wolfram Keller, Gisela Westhoff, Reiner Dilg, Robert Rohner, Hans Henning Studt." Efficacy and cost effectiveness aspects of outpatient (Jungian) psychoanalysis and psychotherapy--a catamnestic study". In Target, M.; Leuzinger-Bohleber, M. (Eds.) Outcomes of psychoanalytic treatment: Perspectives for therapists and researchers. (pp. 186-197). Philadelphia, PA, US: Whurr Publishers, 2002. 
[37] Calvin A. Colarusso. "A child-analy tic case report: A 17-year follow up". In Cohler, B. J., Bertram, J. \& Cohen, J. (Eds.) The psychoanalytic study of lives over time: Clinical and research perspectives on children who return to treatment in adulthood. (pp. 49-65). San Diego, CA, US: Academic Press. 2000.

[38] Landrum Jr. Tucker. "The Grandparent Syndrome: A Case Study". The Psychoanalytic Study of the Child., vol 61, pp 82-98. 2006.

[39] Jean C. Yi. "Ethnic minorities in couple therapy: A five-year follow up". Dissertation Abstracts International:-Section-B:The-Sciences-and-Engineering, vol 68, no 7, p. 4853. 2008.

[40] Ulf Wallin, Per Kronvall. "Anorexia nervosa in teenagers: Change in family function after family therapy, at 2-year follow up". Nordic Journal of Psychiatry, vol 56, no 5, PP. 363-369. 2002.

[41] Angela C. Gebara, Jose Tolentino Rosa, Ryad Simon, Kayoko Yamamoto. "Eficácia terapêutica da interpretação teorizada na psicoterapia breve". Psic: Revista de Psicologia Vetor, vol 5, no 1, pp. 6-15. 2004.

[42] Diva da Silva Oliveira. "O uso do aparelho de alarme no tratamento comportamental da enurese infantil noturna". 110f. Dissertação (Mestrado em Psicologia) - Instituto de Psicologia, Universidade de São Paulo. 1999.

[43] Rosemar Aparecida P. Silva, Marilia Alves Facco, Edwiges F. M. Silvares. "Enurese noturna infantil. Tratamento comportamental com aparelho de alarme e seguimento como controle de recaída: estudo de caso". Jornal Brasileiro de Psiquiatria Rio de Janeiro, vol 53, no 2, pp. 113-122. 2004.

[44] Egberto R. Turato. "Tratado da metodologia da pesquisa clínico-qualitativa: construção teórica-epistemológica, discussão comparada e aplicação nas áreas da saúde e humanas". Petrópolis: Vozes. 2003.
[45] Camila L. Pavanelli. "A teoria como objeto interno do analista e seus destinos na clínica: luto e melancolia como metáfora". 139f. Dissertação (Mestrado em Psicologia) Instituto de Psicologia, Universidade de São Paulo. 2007.

[46] Teresinha Féres-Carneiro. "Casamento contemporâneo: o difícil convívio da individualidade com a conjugalidade". Psicologia: Reflexão e Crítica, vol 11, no 2, pp. 379-394, 1998.

[47] Sigmund Freud. "História de uma neurose infantil". In: História de uma neurose infantil e Outros trabalhos. Rio de Janeiro: Imago. p.131-151 (Trabalho original publicado em 1918). (Edição Standard Brasileira das Obras Psicológicas Completas de Sigmund Freud, XVII). 1980.

[48] Sigmund Freud. "Análise terminável e interminável". In: Moisés e o Monoteísmo, Esboço de Psicanálise e outros Trabalhos. Rio de Janeiro: Imago. p.239-287. (Trabalho original publicado em 1937). (Edição Standard Brasileira das Obras Psicológicas Completas de Sigmund Freud, XXIII). 1980.

[49] Maria G. Rios, Isabel C. Gomes. "A inclusão de um bebê em sessões de psicoterapia psicanalítica de casal com seus pais: relato de um caso". In Gomes, I.C. (Coord.). Família: Diagnóstico e Abordagens Terapêuticas. Rio de Janeiro: Guanabara-Koogan. 2008.

[50] Janine Puget, Isidoro Berenstein. "Psicanálise do casal". Porto Alegre: Artes Médicas. 1993.

[51] Antonio Carlos Gil. “Estudo de caso”. São Paulo: Atlas, 2009.

[52] Fernanda Barcellos Serralta, Maria Lucia Tiellet Nunes, Claudio Laks Eizirik. "Considerações metodoló gicas sobre o estudo de caso na pesquisa em psicoterapia". Estudos de Psicologia, vol. 28, no 4, PP. 501-510, 2011. 